\title{
ENSAIO SOBRE O CONTEÚDO JURÍDICO DO PRINCÍPIO DA LUCRATIVIDADE
}

\author{
FERNANDO FACURY SCAFF*
}

1. De que Direito Estamos Falando? - 2.Fundamentos do Sistema Capitalista. - 2.1 Características do Estado Liberal: a) O Princípio da Legalidade, b) Separação de Poderes, c) Voto censitário, d) Liberdade Contratual, e) Propriedades privadas dos meios de produção e o fator trabalho, f) $O$ incremento da busca por excedente de mais-valia. - 2.2 Causas do início da intervenção do Estado na economia. - 2.3 Transformações no regime econômico para manutenção do sistema: de liberal para intervencionista. - 3. O Princípio da Lucratividade. - 3.1 O conceito de economicidade. - 3.2 Elementos para a construção do conceito. - 3.3 Limitação de lucro e prejuízo. - 4. Conclusões. Bibliografía.

\section{De que Direito estamos falando?}

O Direito é um produto cultural de uma certa sociedade. Não é haurido do céu, ou revelado por sábios jurisconsultos que o tenham descoberto em prateleiras empoeiradas de bibliotecas medievais. Decorre de nossa história de vida ${ }^{1}$.

A assertiva de que o Direito é um produto cultural nos leva a constatar que não existe um Direito, mas Direitos, fruto das diversas variações possíveis em um grupamento humano: econômicas, temporais, espaciais, psíquicas etc. ${ }^{2}$.

1 "Las normas jurídicas depositadas en la Constitución, las leyes, los reglamentos, las sentencias judiciales, etc., son pedazos de vida humana objetivada, son objetivaziones de la vida humana, son objetos culturales." Recaséns Siches. Introduccion al Estudio del Derecho, $12^{2}$ ed. México, Ed. Porrúa, 1997.

* Advogado, Doutor em Direito pela USP - Universidade de São Paulo, professor da Universidade Federal do Pará (graduação e mestrado), e professor convidado da Universidade Federal de Pernambuco (mestrado e doutorado). e-mail: ffscaff @supridados.com.br

2 Ver, entre outros, Eros Roberto Grau, O Direito Posto e o Direito Pressuposto; SP, Malheiros, 
Desta forma, não se há de falar na existência ontológica do Direito, mas de um Direito datado de conformidade com uma certa sociedade, em um dado período de tempo, de acordo com a cultura desse tempo ${ }^{3}$

Logo, ao tratarmos de Direito, somos obrigados a mencionar de que Direito se trata. E, para a presente análise, deve-se alertar o leitor para o fato de que, após a análise teórica, estar-se-á a falar do Direito brasileiro, construído para a Constituição Federal de 1988 - portanto, decorrente dos embates sociais existentes no período anterior, principalmente nos anos 70 e 80 , onde a perspectiva social era de defesa do cidadão contra o Estado, seja no âmbito dos direitos civis e das liberdades públicas, seja na perspectiva da defesa do contribuinte, assolado por um Estado que impunha exações à força, tais como empréstimos compulsórios nunca devolvidos e impostos instituídos através de normas infralegais ${ }^{4}$.

Assim, a Constituição Federal de 1988 surgiu como um instrumento de defesa do cidadão contra o poderio do Estado, mas também como um instrumento construtor de uma nova cidadania, implementadora de políticas públicas que permitissem a realização de diversas finalidades estabelecidas na Carta: sociais, educacionais, previdenciárias, ambientais, de proteção às minorias etc. Vários capítulos da Carta sinalizam neste sentido.

Visualizava-se a construção de um Brasil melhor do que o anteriormente existente, o florescer de uma nova cidadania.

Contudo, de imediato, grande parte deste ideário ficou apenas no papel, porque o Direito, fruto da cultura, não mudou. Mudaram as normas, e não as pessoas para ser mais preciso, não mudou de estalo a cultura das pessoas, dentre elas, os operadores jurídicos. A cultura é fruto de processos cognitivos e, como tal, requer tempo para sua consolidação, muito embora o surgimento de uma nova norma já traduza uma mudança cultural, todavia insuficiente para sua plena efetividade.

A existência de normas escritas é de suma importância para dar a segurança e a certeza necessárias para o desenvolvimento de uma sociedade, mas não é o bastante. A praxis ${ }^{5}$ é fundamental para o desenvolvimento do Direito, o que não ocorre apenas

1996, item 1.2. Também Óscar Correas, Sociología del Derecho y Crítica Jurídica, México, Ed. Fontamara, 1998, item 8 . Faço observar que não estou convencido de que o Direito frui unicamente do modo econômico de produção, mas certamente ele é um dos seus componentes mais determinantes, dentre vários outros.

3 "A instrução é mera transmissão de conhecimentos, de técnicas, de habilidades. A educação, um trabalho de formação de personalidades. E, no caso, um trabalho de formação de cidadania, para o exercício de cidadania. A educação no pensamento grego é o que se chama cultura, cultura do corpo e cultura da alma." Fábio Konder Comparato, Educaçāo, Estado e Poder. SP, Brasiliense, 1987 , p. 92.

4 O Plano Cruzado, que durou os anos de 86-87 é pleno destas figuras nefastas. Ver, para a questão da geraçāo de direitos fundamentais, Paulo Bonavides. Curso de Direito Constitucional. SP, Malheiros, $5^{2}$ ed., 1994, Capítulo 16, págs. 514-29.

5 "Atividade humana perceptível em que se resolve o real concebido subjetivamente", definição retirada do verbete "praxis", elaborado por Gustavo Gozzi, do Dicionário de Política, organizado por Norberto Bobbio et alii. Brasília, Ed. UnB, 1992, vol. 02, pág. 987. 
com a instauração de normas. Daí porque não basta a criação de normas - como efetuado através da Constituição Cidadã -, mas é necessário que a cultura das pessoas também mude, a fim de que tais normas (que por si só já revelam uma mudança) possam ser por elas implementadas, de conformidade com os novos paradigmas existentes. Não basta que uma norma crie um fantástico instituto garantidor da efetividade da Constituição, como o mandado de injunção, quando a interpretação desta norma pela Corte Suprema leva ao seu completo esvaziamento.

Desta forma, não é suficiente que um complexo de normas seja criado - como foi a Constituição de 1988. É necessário que todo um outro conjunto de fatores seja alterado para que a implementação daquela norma seja efetivada. $E$ isto decorre de um fator cultural. E para que haja a efetiva implementação do Direito, é necessário que este fator cultural seja maturado ao longo de um tempo. Daí porque somente após passados alguns anos, e de algumas modificações no aparelho judiciário, especialmente nas Cortes Superiores, é que os principais institutos constitucionais começam a ser efetivados de forma diferente da visão anteriormente existente, então arraigada no viés centralista, conservador e sobretudo autoritário da Constituição de $1969^{6}$

Direito bom é Direito velho, diz o dito popular ${ }^{7}$. Não se trata de conservadorismo, mas é um fator de consolidação das possíveis interpretações das normas, e de pacificação prudencial ${ }^{8}$ e jurisprudencial pelos Tribunais e pela sociedade.

Não basta que haja uma mudança normativa. É necessário que haja uma mudança interpretativa referente às novas normas surgidas. E tal fato decorre desta mudança cultural que falamos - o que requer uma praxis. E isto implica também no fator tempo; o que as constantes modificações constitucionais não estão permitindo. Na verdade, vive-se no Brasil em permanente processo de revisão constitucional. Parece mesmo que a Constituição de 1988 se transformou em uma imensa medida provisória ...

Assim, é fundamental que se analise um Direito (e não $o$ Direito) sob o prisma de sua aplicação efetiva, e não sob o preceito estático das normas dispostas em um dado ordenamento. Elas se configuram em um fator importante, relevantíssimo, mas não único, e sequer determinante. A norma surge; é texto sobre papel. A interpretação é o dado fundamental, pois decorre de uma ação humana cotidiana, diuturna, intermitente, e efetivamente aplicadora da norma - a qual é tão-somente texto sobre papel. E interpretar significa que a cultura do sujeito que promove a ação exegética é determinante para o resultado da análise e da implementação daquele texto. Ou seja, não existe uma única interpretação possível, mas tantas quantas sejam os intérpretes. E existem interpretações que traduzem diversas possíveis percepções da realidade e outras que se constituem em singelos devaneios, logo, inaceitáveis.

Daí que a ação de interpretar é fundamental para o tipo de Direito que temos; e o tipo de cultura existente entre os intérpretes é de suma importância para a efetividade do Direito que temos.

6 Terá sido efetivamente uma Constituição? Ou lhe terá feito às vezes, como uma pantomima?

7 Que Geraldo Ataliba magistralmente utilizou como o adágio Imposto bom é imposto velho.

8 Prudencial referente à aplicação destas normas pela sociedade, e não apenas pelo Judiciário. 
É necessário que, em certo momento, haja uma determinação de significação do conteúdo da norma, através de uma interpretação factívelmente aceita pela sociedade, efetivada por quem detenha poderes para tanto. No caso brasileiro, o intérprete final das normas constitucionais é o Supremo Tribunal Federal, que nos indica uma hipótese de Direito em ação, e não apenas de Direito em potência.

\section{Fundamentos do Sistema Capitalista:}

Um primeiro passo para dar conteúdo jurídico ao Princípio da Lucratividade é a constatação de que sua existência decorre do sistema capitalista. É, portanto, imprescindível que sejam efetuadas breves considerações sobre seu surgimento e existência, a fim de ser possível descobrí-lo dentro do sistema.

\subsection{Características do Estado Liberal}

No Estado Absolutista todos os poderes do Estado estavam concentrados nas mãos do soberano, que ou desempenhava as funções de governo ou as delegava a outrem. Assim, o próprio Rei criava uma lei, estabelecia mecanismos para sua implementação e, caso descumprida a norma, julgava os infratores. No Estado Liberal tal situação já não podia viger. A soberania havia sido transferida do Rei, cujo direito de governar provinha de Deus, para o povo. Logo, somente aquilo que o povo quisesse é que poderia ser efetuado pelo Estado.

Diversos princípios foram criados para permitir o desenvolvimento do Estado Liberal, que, de certa forma, representou uma antítese ao Estado Absolutista, posto que, então, a burguesia passou a dirigir a máquina estatal diretamente, e não como mais um ator em cena. Com a positivação do direito privado, anteriormente calcado quase que exclusivamente em direito consuetudinário ${ }^{9}$, foi possível ao Estado determinar a condução dos negócios dos agentes privados a seu bel-prazer. Assim, durante o período em que vigorou o Estado Liberal, a determinação da política econômica era no sentido de não intervir nos negócios privados, deixando que eles fluíssem ao sabor do mercado. A seguir listaremos alguns dos institutos que caracterizaram política e economicamente o Estado Liberal e seu absenteísmo.

\section{a) Princípio da Legalidade}

O Princípio da Legalidade é decorrente do Princípio da Soberania Popular acrescido do Princípio da Representação Popular. Assim, como cada pessoa é possuidora de uma parcela da soberania do Estado (Princípio da Soberania Popular), ela deve ser ouvida em todas as decisões que o Estado tome, uma vez que age em nome e por conta de cada qual do povo. Contudo, ante a impossibilidade fática de 
cada indivíduo estar presente no momento da discussão das decisões a serem tomadas pelo Estado, surgiu a idéia de que todo o povo poderia ser representado por apenas um pequeno número de pessoas, para as quais seria outorgado um mandato eletivo. Tudo elaborado de tal forma que, ao fim, todo o povo de um Estado pudesse estar representado na tomada, e para a tomada, de decisões (Princípio da Representação Popular).

Este grupamento representativo da soberania popular, designado Parlamento, exerce a função de estabelecer quais as decisões que o Estado deve tomar. Estas decisões são denominadas "lei", e têm as características de serem gerais, abstratas e vinculativas. Gerais para abranger a toda a coletividade; abstratas a fim de que tratem de casos em tese, e não de problemas concretos e específicos; e vinculativas para obrigar todos ao cumprimento daquele determinado comportamento descrito.

Tais características visavam impedir a criação de privilégios por parte da lei, ou melhor, por parte daqueles que faziam a lei, uma vez que foi em razão de privilégios que o Estado Absoluto havia sido extinto. Sendo todos os homens livres e iguais, conforme pregava a doutrina liberal, a lei não poderia criar privilégios entre eles.

Para o desenvolvimento deste mecanismo jurídico foi também necessário criar a Separação de Poderes.

\section{b) Separação de poderes}

No Estado Absolutista todos os poderes ficavam reunidos nas mãos do soberano. Daí porque a este tudo era permitido, não estando nem mesmo sujeito às leis que ele próprio criava. No Estado Liberal foi elaborado um mecanismo de Separação de Poderes a fim de que ninguém pudesse dispor sozinho de todo o poder do Estado.

Foi constatado que as principais funções do Estado eram as de legislar, administrar e julgar; para exercer essas funções foram criados órgãos distintos, harmônicos entre si. Surgiu daí o Poder Legislativo, o Poder Executivo e o Poder Judiciário. Ao Poder Legislativo coube a função de legislar; ao Executivo, a de administrar; e, ao Judiciário, a de julgar as infrações cometidas. Desse modo, ninguém poderia ter em suas mãos todo o poder do Estado; foi, então, criado um sistema de freios e contrapesos que possibilitaria o equilíbrio entre esses órgãos. É patente a preocupação dos liberais de não permitir a reimplantação do Absolutismo.

\section{c) Voto censitário}

Para que se possa afirmar que a burguesia passou a controlar o Estado, além dos fatos já demonstrados retro, é necessário que se analise a racionalidade do sistema eleitoral da época.

Era usual ser estabelecido nas Constituições um critério de renda para que fosse possível a participação no processo eletivo. Somente aqueles que fossem burgueses (termo agora utilizado para designar aquelas pessoas possuidoras de capital), ou que 
tivessem um grau superior de instrução, é que poderiam votar ou ser votados para ocupar cargos no Estado, o que mantinha fora do sistema a imensa maioria do povo ${ }^{10}$.

O Parlamento era então o representante direto de toda a burguesia, que, dessa forma, transformou seus próprios ideais em aspirações de toda a sociedade. Como no Poder Legislativo só podiam participar pessoas da burguesia, não é mera figura de retórica dizer que a burguesia controlava o poder do Estado durante o Estado Liberal. E, consequientemente, as ações e inações estatais desse período somente ocorreram porque assim convinham a essa classe.

Dentro desta ideologia, ao Estado era lícito atuar sob três aspectos: para manutenção da ordem, da segurança e da paz; ou seja, da paz, em nível de política externa, para que internamente fosse possível ocupar todo o tempo e todo o pessoal disponível com atividades propriamente econômicas; da ordem em nível de política interna, evitando a transgressão às leis estabelecidas pela burguesia através do Parlamento; e da segurança nas relações econômicas, fazendo com que a propriedade privada e os contratos fossem respeitados tal qual prescritos, e, em caso de seu descumprimento, responsabilizando o infrator.

O Estado absenteista nas relações econômicas permitia que a burguesia mantivesse e reproduzisse as condições objetivas de produção.

\section{d) Liberdade contratual}

A doutrina econômica liberal pode ser resumida na seguinte frase: laisser faire, laisser passer. Pronunciavam-se os liberais contra toda e qualquer forma de intervenção do Estado na economia. Segundo eles, o homem era guiado pelo princípio hedonista; logo, havendo um grau absoluto de liberdade em relação ao Estado, mecanismos invisíveis fariam com que se estabelecessem regras para a satisfação geral. Quanto mais cada indivíduo buscasse de satisfação própria, mais ele estaria fazendo em prol da comunidade. A somatória de "egoísmos" resultaria em maior beneficio geral.

Seria a busca da maior satisfação com o menor custo possível no âmbito econômico que faria entrar em ação uma "mão invisível", determinante do maior preço possível de se obter por um produto, indicando assim seu real valor em face de sua procura pelos consumidores.

Esta "mão invisível" seria o mercado, onde todas as trocas deveriam realizar-se na maior liberdade possível. Todos os produtores e consumidores deveriam encontrar-se no mercado, onde, em razão da procura, a oferta estabilizaria seus preços. $O$ hedonismo econômico no mercado acarretaria o maior nível de bem-estar possível para toda a coletividade. Os consumidores comprariam ao menor preço possível e

10 Ver Ferdinand Lassale, Que é uma Constituição?, p. 37-9; Charles Beard, Una interpretación econômica de Ia Constitución de los Estados Unidos, p. 160-5; Massimo Severo Giannini, Diritto pubblico dell'economia, p. 26-7; e também Friedrich Müller, Quem é o Povo? A Questão Fundamental da Democracia. 
os produtores venderiam ao menor preço possível. A medida da possibilidade seria dada pelo mercado. Este é o funcionamento teórico da lei da oferta e da procura.

Decorre daí um dos principais instrumentos do capitalismo liberal, que é a liberdade para contratar. As relações têm que ser livres porque todos os homens nascem iguais. Os critérios diferenciadores dos homens - os títulos nobiliárquicos - eram prejudiciais e não deviam sobrexistir. Logo, a plena liberdade de troca nos mercados entre homens livres e iguais foi condição essencial para o desenvolvimento do Estado Liberal.

Observe-se que o mercado não surgiu com o Estado Liberal pois existia desde há muito. Todavia, sempre foi um elemento periférico ao sistema, diversamente do que passou a ocorrer com o surgimento do Estado Liberal, no qual o mercado cumpre um papel fundamental.

\section{e) Propriedade privada dos meios de produção e o fator "trabalho"}

Outro princípio basilar do Estado Liberal é a propriedade privada dos meios de produção. Para que o sistema liberal se desenvolvesse era necessário que todos os indivíduos fossem proprietários, a fim de que pudessem realizar trocas no mercado. Portanto, para que pudessem realizar trocas, era requisito básico que todos tivessem alguma coisa para permutar. Daí a tese de que todo indivíduo, por mais não-proprietário que fosse, sempre teria algo para trocar com outrem: sua força de trabalho. E para remuneração dessa troca de força de trabalho por dinheiro no mercado havia um preço denominado "salário". Assim, o contrato de aluguel de força de trabalho era mais um contrato, igual a outros tantos, entre pessoas livres. Salário seria então o pagamento pelo aluguel de força de trabalho, a contraprestação econômica de um contrato de trabalho firmado entre duas pessoas igualmente livres.

E, como já havia sido constatado no período de crescimento urbano que a divisão de trabalho ocasiona maior produtividade, a força de trabalho especializada obtinha maior remuneração que a não-especializada.

Ressalte-se, contudo, que não foi com o Estado Liberal que surgiu o assalariamento, o aluguel de força de trabalho. Mas foi no Estado Liberal, marcado pela Revolução Industrial, que tal fato prosperou, em face da idéia de liberdade contratual e da necessidade daqueles não-proprietários em alugar o único bem que possuíam - sua força de trabalho. A característica deste período foi a formação de um "exército de reserva", fruto de maior oferta de mão-de-obra do que de procura por parte das empresas. Tal fato ocasionava o pagamento de um salário vil em razão da multidão de não-proprietários que precisavam vender sua força de trabalho para sobreviver.

Assim, para os burgueses, proprietários de capital, era fácil efetuar trocas no mercado com aquelas pessoas que somente possuíam sua força de trabalho. Os burgueses trocavam seu capital pela força de trabalho do operariado, ocasionando o pressuposto liberal de que todos são proprietários dos meios de produção — os burgueses, do capital; os trabalhadores, de sua força de trabalho. Dentro desses parâmetros é que se pode verificar a supremacia daqueles que possuíam o capital, posto que somente eles é que 
podiam comprar os insumos básicos necessários para que sobre eles a força de trabalho atuasse. É facilmente constatável que, neste período, a força de trabalho tinha menor importância no sistema produtivo em face do capital.

\section{f) $O$ incremento da busca por excedente de Mais-valia}

É aí que se encontra o gérmen do sistema - na apropriação privada da maisvalia produzida pelos trabalhadores em razão do aluguel de sua força de trabalho no mercado e a incessante busca por seu aumento. Este é o ponto básico.

A partir do assalariamento, ou seja, da locação da força de trabalho consoante o mercado, e da consideração desta como apenas mais uma mercadoria dentro do sistema produtivo, cujos resultados são de apropriação privada, é que temos a essência do sistema. A apropriação privada da "mercadoria" trabalho faz gerar a mais-valia, que se consubstancia em um sobreproduto social deixado pelos trabalhadores nas mãos dos proprietários dos meios de produção, ao fim de um período de trabalho. A incessante busca pelo aumento da jornada de trabalho com aumento de produtividade acarreta o incremento da mais-valia.

"Por não se poder ver direta e imediatamente a extração da mais-valia no processo produtivo, o lucro do capitalista não aparece como uma parte do valor não-pago gerado pelo uso da força de trabalho, mas como produto efetivo do capital, contrastando, em contrapartida e igualmente, pela aparência de que mediante os salários se paga 'realmente' todo o trabalho do produtor", segundo Alaôr Caffé Alves ${ }^{11}$.

A extração da mais-valia sempre ocorreu. Marx expõe com brilhantismo esta situação ao mencionar que "onde quer que parte da sociedade possua o monopólio dos meios de produção, o trabalhador, livre ou não, tem de adicionar ao tempo de trabalho necessário à sua autoconservação um tempo de trabalho excedente destinado a produzir os meios de subsistência para o proprietário dos meios de produção, seja esse proprietário aristocrata ateniense, teocrata etrusco, cidadão romano, barão normando, escravocrata americano, boiardo da Valáquia, senhor de terras moderno ou capitalista. (...) Entretanto estas constituem exceções no mundo antigo. Tão logo porém os povos, cuja produção se move ainda nas formas inferiores do trabalho escravo, corvéia etc., são arrastados a um mercado mundial, dominado pelo modo de produção capitalista, o qual desenvolve a venda de seus produtos no exterior como interesse preponderante, os horrores bárbaros da escravatura, da servidão etc. são coroados com o horror civilizado do sobretrabalho. Por isso, o trabalho dos negros nos Estados sulistas da União Americana preservou um caráter moderadamente patriarcal, enquanto a produção destinava-se sobretudo ao autoconsumo direto. Na medida, porém, em que a exportação de algodão tornou-se interesse vital daqueles Estados, o sobretrabalho dos negros, aqui e ali o consumo de suas vidas em 7 anos de trabalho, tornou-se fator de um sistema calculado e calculista. Já não se tratava de obter deles certa quantidade de produtos úteis. Tratava-se, agora, da produção da própria mais-valia." 12

11 Estado e ideologia; aparência e realidade, p. 173

12

O Capital, vol. I, pág. 190-1. 
Os vassalos possuíam seus meios de produção, e destinavam uma parcela de seu trabalho para pagar suas obrigações feudais com o susera-no. Havia mais-valia, contudo a sistemática feudal que compunha o sistema produtivo era determinada por status, e não consoante o nível de produção ou de produtividade. Não havia um mercado de trabalho para que se formasse o "exército assalariado de reserva". Ademais, nem sempre as obrigações feudais eram pagas com sobretrabalho, mas também poderiam sê-lo com o fruto do trabalho. Além da existência do subenfeudamento, que transferia para terceiros vassalos as obrigações assumidas perante seu próprio suserano. Logo, também não se há de falar em busca incessante pela maisvalia naquela época.

No Estado Liberal a plena liberdade contratual e o pressuposto da propriedade privada dos meios de produção fizeram com que o trabalhador somente tivesse sua força de trabalho para trocar no mercado, a qual, somada ao capital, produz rendimentos. Para o trabalhador fica o salário; para o capitalista, o lucro. Assim, embutida na quantidade de trabalho há uma parcela de sobretrabalho que determinará o lucro do capitalista, obviamente acrescido de outros fatores aleatórios.

Esta dissociação entre o produtor e os meios de produção, que tem como pressupostos básicos a plena liberdade de contratação e a propriedade privada dos meios de produção, é uma das características fundamentais do sistema, pois, juntamente com outros fatores, gerou a possibilidade do incremento da mais-valia.

É o aluguel, no mercado, da força de trabalho, e não a venda do produto do trabalho, um dos fatores que ocasiona a mais-valia. Por outras palavras, é o aluguel da mercadoria "força de trabalho", e não de um produto onde está embutido o trabalho, que caracteriza o sistema. $O$ trabalhador, em virtude de não possuir outra alternativa para sobreviver e em face de não ter condições de vender o produto de seu trabalho, pois não tinha capital para comprar os meios de produção, foi obrigado a passar a alugar sua força de trabalho ao proprietário do capital, que o embute no preço dos produtos que vende, e obtém daí um lucro, uma mais-valia, de apropriação privada, posto que os meios de produção são de propriedade privada. Para o trabalhador apenas resta o valor locatício de sua força de trabalho.

\subsection{Causas do início da intervenção do Estado na economia}

Os motivos que ocasionaram o início da intervenção do Estado na economia são inúmeros; contudo, listaremos a seguir apenas os que nos parecem mais importantes:

$\left.1^{\circ}\right)$ A liberdade generalizada nos mercados propiciou o surgimento de economias de escala que favoreciam posições monopolísticas, o que contrariava a filosofia liberal de mercado. A pulverização necessária entre as unidades econômicas, para que a lei da oferta e da procura pudesse fluir naturalmente, teve uma barreira com o advento dos monopólios e oligopólios nascentes.

Duas posições diversas foram tomadas a partir da ocorrência dos monopólios, segundo Vital Moreira ${ }^{13}$ : 
a) nos EUA surgiram leis "antitruste" que objetivavam combatê-los; e

b) na Alemanha a jurisprudência consagrou que a formação oligopolista era lícita, e daí defluía uma concorrência perfeita.

Na solução americana foi necessário modificar a ordem jurídica para que fosse possível tentar manter o mercado liberal. Já na solução alemã o ordenamento jurídico foi mantido intacto, mas a ordem natural do mercado foi quebrada. Desse modo, àquela época a Alemanha necessitou fortalecer-se economicamente, incentivando os conglomerados de empresas, para fazer face ao poderio inglês que ameaçava seus mercados; para tanto, "deturpou" a ordem econômica liberal de livre concorrência a fim de proteger seus interesses. Nos EUA, onde tal ameaça não pairava, foi necessário alterar a ordem jurídica para manter o sistema econômico liberal, que, por si só, não se manteria, pois o mercado seria dominado por um punhado de grandes empresas $^{14}$.

$2^{\circ}$ ) O funcionamento do mercado levou à ocorrência de crises em períodos aproximadamente decenais, caracterizadas por estocagem e desemprego. Segundo Fábio Nusdeo ${ }^{15}$, entre outros fatores, tais crises eram ocasionadas pela deficiência de mobilidade dos meios de produção. Quando um agricultor planta determinada cultura em razão de seu preço atual de mercado ser elevado, terá de esperar um lapso de tempo para que ocorra a colheita, e é possível que até tal data o preço de mercado para aquela cultura não seja mais compensador. Dai dizer-se ter sido a dificuldade de mobilidade dos fatores de produção uma das causas das crises periódicas do regime econômico liberal, pois todos os riscos da produção recaiam sobre o capitalista.

$3^{\circ}$ ) Outra causa relatada por $\mathrm{Nusdeo}^{16} \mathrm{diz}$ respeito à presença de efeitos externos à produção e que não podem ser apurados pelo mercado. $O$ exemplo de um efeito positivo, também chamado de "economia externa", seria o de "uma fábrica que investisse determinada importância no treinamento de seus operários, os quais, após um certo tempo, iriam se empregar em outras indústrias da região. Estas últimas estariam se beneficiando da maior qualificação de seus novos auxiliares, sem terem empregado qualquer recurso próprio para esse fim".

Os efeitos externos negativos, ou "deseconomias externas", são mais comuns, por exemplo, poluição, congestionamento, esgotamento dos recursos naturais etc. Estes também não são computados no custo dos bens produzidos. Se o fossem, o preço destes subiria e o consumo decresceria, reduzindo os efeitos nocivos.

Ademais, o princípio hedonista do Estado Liberal não traduziu um provimento de bens públicos em níveis satisfatórios, uma vez que os canais do mercado não foram criados para satisfazer. estas necessidades, mas para a produção de bens de uso pessoal. Carros em detrimento de metrôs, indústrias ao invés de praças etc.

14 Este aspecto foi também observado por Véra Jacob de Fradera no artigo A Integração Européia e o Mercosul: Confronto Atual, Direito da Concorrência e Integração em Perspectiva Comparatista Rev. de Direito do Consumidor, vol. 31, ano 99, págs. 86-95.

15 Da política econômica ao direito econômico, cit., p. 38-41

16 Da política econômica ao direito econômico, p. 43 
$4^{\circ}$ ) Alguns estudos econômicos desenvolvidos no apogeu do Estado Liberal caminharam no sentido de uma negação do mercado e para a total planificação da economia, gerando benefícios coletivos. São as teorias socialistas, que negavam o instituto do mercado e viam o liberalismo como um sistema fadado à destruição. Esses estudos teóricos ocasionaram a mitigação de inúmeros institutos do liberalismo, surgindo daí um regime intervencionista. Assim, por mais curioso que possa parecer, a "antevisão" de uma destruição do mercado - pelas previsões socialistas - fez com que o próprio Estado Liberal se modificasse, adotando uma nova postura (intervencionista), que cumpria a função de modernizá-lo e de permitir sua expansão, agora custeado pelo Poder Público.

Em nível teórico poder-se-ia falar em tese liberal, antítese coletivista e síntese intervencionista ou de iniciativa dual, como expõe Geraldo de Camargo Vidigal. ${ }^{17}$

Contudo, cabe ressaltar que o Estado Socialista não foi um fato concreto, mas uma previsão acerca do Estado Liberal que não se concretizou.

O Estado Socialista consiste em uma etapa de transição para o alcance do comunismo, onde, então, não mais existiria o Estado. Sua característica básica é a reunião de todas as atividades econômicas nas mãos do Estado e a transformação da democracia representativa em democracia direta. Não mais haveria a separação entre o trabalhador e os meios de produção, uma vez que não mais existiriam proprietários, e todos os meios de produção pertenceriam a todos os indivíduos, ao Estado. Dai que a repartição da mais-valia seria efetuada consoante a capacidade de cada qual. Em uma segunda etapa, ao fim da transição, a quando da instalação do comunismo, não mais se poderia falar em mais-valia, posto que a repartição do produto social passaria a ser efetuada de conformidade com as necessidades de cada indivíduo.

Expostas estas características do Estado Socialista, pode-se verificar que nunca existiu, na prática, nenhum Estado que com tal plataforma teórica se assemelhasse, muito embora inúmeros Estados se denominassem socialistas. Constata-se que ao invés de um tipo de Estado como o Socialista surgiu o Intervencionista, ao qual não se assemelha, a despeito da opinião diversa de José Afonso da Silva ${ }^{18}$ e de Paulo Bonavides ${ }^{19}$.

$5^{\circ}$ ) Vital Moreira dá como causa da transformação do Estado Liberal em Intervencionista o fato de ter sido considerada a venda de força de trabalho como a venda de uma qualquer mercadoria. $O$ trabalhador não vende sua força de trabalho porque quer, mas por ter de utilizá-la para sua sobrevivência. "A liberdade do contrato transmuda-se na necessidade de aceitar as condições de um poder econômico mais forte" ${ }^{20}$. Ademais, como a quantidade de mão-de-obra é mais numerosa e pulverizada no mercado do que o capital, este levava vantagem no ato de contratar.

17 Teoria geral do direito econômico, cit., p. 14-8.

18 Aplicabilidade das normas constitucionais, p. 126

19 Do Estado Liberal ao Estado Social, cit., p. 209 e s.

20 A ordem jurídica do capitalismo, cit., p. 80 
Marx expunha esta tese atacando o sistema capitalista e, de certa forma, desonerando os capitalistas: "O capital não tem, por isso, a menor consideração pela saúde e duração da vida do trabalhador, a não ser quando é coagido pela sociedade a ter consideração. (...). De modo geral, porém, isso também não depende da boa ou má vontade do capitalista individual. A livre concorrência impõe a cada capitalista individualmente, como leis externas inexoráveis, as leis imanentes da produção capitalista." 21

E, em nota de rodapé, recheada de dados históricos, como era bem de seu gosto, Marx dispôs sobre o pedido que os capitalistas faziam para que o Estado interviesse a fim de regular a concorrência predatória que havia se formado por sobre a miséria humana: "Assim, verificamos, por exemplo, que no começo de 1863, 26 firmas proprietárias de grandes cerâmicas em Staffordshire, entre elas, J. Wedgoog e Filhos, num memorial pedem 'a enérgica intervenção do Estado'. A 'concorrência com outros capitalistas' não lhes permite nenhuma limitação 'voluntária' do tempo de trabalho das crianças etc. 'Por mais que lamentemos os males acima mencionados, seria impossível impedi-los por meio de qualquer espécie de acordo entre os fabricantes (...) Considerando todos esses pontos, chegamos à convicção de que é necessária uma lei coativa'." 22

$6^{\circ}$ ) A derrocada do regime foi acelerada pela Primeira Guerra Mundial, que transformou a face do mundo e iniciou novo capitulo nas relações econômicas. Surgiu a necessidade de o Estado atuar para organizar as atividades produtivas, direcionando-as para o esforço de guerra, o que abriu caminho para uma experiência intervencionista concreta. A guerra provocou a destruição do mercado "natural" e ocasionou enormes perdas, requerendo a atuação do Estado no sentido de evitá-las, além de provocar o aumento numérico e o surgimento de uma consciência de classe entre os operários, cuja organização se intensificou nesta época, e cujo poder político passou a ser mais respeitado, possibilitando o enfrentamento aos proprietários dos meios de produção ${ }^{23}$.

\subsection{Transformações no Regime Econômico para manutenção do Sistema: de liberal para intervencionista}

Qualquer expressão que denote "intervenção" do Estado no domínio econômico é, em si, temerária, pois induz a crer que o Estado e a economia são coisas distintas, e que ao agir no domínio econômico o Estado o faz em um lugar que não lhe é próprio. Cremos que tal concepção de separação entre o econômico e o político não tem como subsistir.

Diz Massimo Severo Giannini ${ }^{24}$ que historicamente o Estado sempre atuou visando, pelo menos, organizar o sistema econômico existente. Assim, nas grandes

21 Ob. cit., pág. 215.

22 Ob. cit., loc. cit., nota de rodapé $n^{\circ} 114$, la. parte

23 Fábio Konder Comparato, Ensaios e pareceres de direito empresarial, p. 455-60

24 Diritto pubblico dell'economia, cit., p. 19-24. Ver também Augusto de Atayde, Estudos de direito econômico e de direito bancário, p. 18-22 
civilizações da Antigüidade, na beira dos rios (Tigre, Eufrates, Nilo etc.), o Estado agia visando o melhor aproveitamento possível da água nas atividades produtivas. Também o fez para unificação de um sistema de tempo-calendário, pesos e medidas, e por aí assim. Segundo Vital Moreira, "a própria existência do Estado e da ordem jurídica significa uma 'intervenção': o Estado e a ordem jurídica são pressupostos inerentes à economia" 25 .

Então, o que caracterizaria o Estado contemporâneo como "intervencionista", já que ele o é desde há muito? Temos que a chave para solução desta questão somente pode ser encontrada quando se contrapõe historicamente os diversos regimes econômicos. Dai surge que no Estado Liberal o Estado não "intervinha" na economia como dantes. Veja-se, por exemplo, a tentativa de tabelamento de preços efetuada por Diocleciano durante o Império Romano, ou mesmo a minuciosa regulamentação mercantilista, característica do Estado Absolutista.

Admitimos então que o Estado Liberal, mesmo quando agia apenas para manutenção da ordem, da segurança e da paz, intervinha no domínio econômico. Diz-nos Vital Moreira ${ }^{26}$ que "essa atividade do Estado sobre o domínio econômico não seria intervenção, por ser inerente ao Estado, como instância política da formação social. Seria o ponto zero de intervenção".

Assim o Estado "absenteísta" nas relações econômicas permitia à burguesia que se mantivesse e reproduzisse as condições objetivas de produção. E era "absenteísta" porque a burguesia assim o determinava, pois tal lhe favorecia.

Temos então que a burguesia, que havia estatizado as fontes de produção normativa e que possuía o controle do Estado em razão do voto censitário, manteve o Estado "intervindo" apenas nessa "mínima" intensidade, neste "ponto zero de intervenção", pois não lhe interessava que o Estado agisse além desse patamar. E estas são as características do Estado Liberal: Liberdade Contratual e Propriedade Privada dos Meios de Produção, que ocasionam o incremento da obtenção de mais-valia. Tanto o Princípio da Legalidade quanto a Separação de Poderes serviram de instrumento para que aquelas características econômicas fossem mantidas.

Podemos concluir que os mecanismos liberais propiciaram à economia uma ordem livre, mas que não era natural, posto que criada pelo Estado, que intervinha na economia no "ponto zero", diversamente do que era praticado anteriormente.

Seguindo este raciocínio, admitimos que o conceito de "intervenção cio Estado no domínio econômico" e o de "não-intervenção do Estado no domínio econômico" têm a mesma matriz, ou seja, os aspectos econômicos são estruturalmente dominantes sobre os aspectos políticos. Por outras palavras: o poder econômico domina os aspectos políticos e através de normas juridicas dirige o Estado para que atue da maneira que mais interessar àqueles - intervindo ou não intervindo.

Logo, temos que o Estado contemporâneo somente pode ser considerado como intervencionista no domínio econômico se contraposto ao Estado Liberal, em que a intervenção também ocorreu, apenas que no "ponto zero". Os demais tipos de Estado

25 A ordem jurídica do capitalismo, cit., p. 198-9

26 A ordem jurídica do capitalismo, cit., p. 199 
que visualizamos retro eram igualmente intervencionistas no domínio econômico, em graus superiores ao que convencionamos chamar de "ponto zero de intervenção", típico do Estado Liberal.

Concluído este raciocínio, julgamos que a intervenção estatal no domínio econômico não cumpre papel socializante; muito pelo contrário, cumpre, dentre outros, o papel de mitigar os conflitos do Estado Liberal, através da atenuação de suas características - a liberdade contratual e a propriedade privada dos meios de produção -, a fim de que haja a separação entre os trabalhadores e os meios de produção.

Decorre daí a necessidade de impor uma "função social" a estes institutos, o que é fundamental para a compreensão do conteúdo jurídico do Princípio da Lucratividade.

Da propriedade com direito de pleno uso, gozo e disposição, passamos a uma exigência funcional da propriedade, sendo determinante sua utilização produtiva e não mais seu título formal.

Igual sentido perpassa pela liberdade contratual, hoje condicionada por um dirigismo econômico estatal, onde não mais existe a livre faculdade de disposição pelas partes, mas um delineamento permissivo ou repressivo de determinadas posições que se consubstanciariam de força, oprimindo a parte hipossuficiente.

O Princípio da Legalidade e a Separação dos Poderes foram mantidos tão-somente sob o aspecto formal, tendo sido, na prática, abrogados. A legislação econômica oriunda do Poder Executivo, que é casuística, com força vinculativa ou não Capacidade Normativa de Conjuntura -, é um fato real, que não condiz com os tipos formais construídos no regime liberal e que lhe deram sustentação, mantendo-se hoje apenas com força mítica. A lei abstrata, geral e vinculativa se torna cada vez mais rara e, mesmo quando advém, a possibilidade aberta para seu detalhamento pelo Poder Executivo é imensa. Assim, tanto o Principio da Legalidade como o da Separação de Poderes se mantêm em nível formal, mas não como característica funcional do período contemporâneo.

Por fim, o voto censitário, que deu ao Estado Liberal um controle total e absoluto sobre a máquina estatal, foi derrogado pela pressão das massas excluídas deste processo. A hipótese, sugerida por alguns, no sentido de que o alargamento da base eleitoral possibilitaria que os sem-propriedade tomassem o poder pois numericamente superiores, constatou-se de efeito diverso. O voto universal foi mesmo uma válvula de escape para a revolução pregada por alguns socialistas, uma vez que possibilitou às massas excluídas a participação no processo político. Contudo, também isto fez com que o Estado Liberal caminhasse para uma transformação, uma vez que foi necessário aumentar o prisma das propostas políticas a fim de alcançar todo este novo eleitorado numericamente superior. Isto determinou o surgimento das normas programáticas, que visam tratar dos temas econômico-sociais, mas que possuem eficácia limitada, segundo José Afonso da Silva ${ }^{27}$. Surge daí a concepção dessas 
normas como políticas, não como jurídicas. Sua função, na realidade, é servir de anteparo às reivindicações sociais para melhoria das condições de vida, uma vez que se torna muito mais difícil reivindicar algo que já foi concedido e consta até mesmo de uma Constituição. Mas, não sendo consideradas jurídicas, não são implementadas; fica ao alvedrio do governante de plantão a sua execução, consoante a lição de Anna de Vita ${ }^{28}$. Não é possível também ser efetuada a cobrança de sua execução perante o Poder Judiciário, pois este poder, segundo a concepção ideológica liberal, não pode imiscuir-se em assuntos políticos, cabendo-lhe apenas o julgamento das leis e não sua execução ou implementação. Estes fatos reforçam a tese de que tais normas, muito embora constitucionais, não se consubstanciam em normas jurídicas, mas em plataformas políticas, em uma verdadeira carta de boas intenções. Tal compreensão, como pode ser constatado, acaba por considerar estas normas como não-jurídicas, o que, para nós, é um falso entendimento, posto que escamoteia e retarda o implemento das conquistas sociais ${ }^{29}$.

Por tudo isso, julgamos que a função primordial da intervenção estatal é mitigar os conflitos existentes no Estado Liberal, e não sua destruição. As características daquele tipo de organização estatal permanecem, mas em dimensão atenuada. $D a$ propriedade privada dos meios de produção passou a viger a função social da propriedade, e da liberdade contratual passou ao dirigismo contratual. Contudo, o primado básico do Estado Liberal se mantém, a despeito de o Estado ter-se transformado em Intervencionista, qual seja: a incessante busca pelo incremento da mais-valia, de apropriação privada pelos detentores dos meios de produção. $\mathrm{O}$ sistema capitalista permanece íntegro, baseado na exploração intensiva da mais valia, minorada pela atenuação das demais características econômicas e políticas que envolvem o sistema. Daí porque se pode afirmar que o sistema econômico permaneceu íntegro, havendo sido modificado apenas o regime, de liberal para intervencionista. Os contornos do direito de propriedade e da liberdade contratual foram mantidos, a separação de poderes e o princípio da legalidade foram relativizados e o princípio do voto censitário extinto, porém a busca incessante pelo incremento da mais valia se mantém de maneira cada vez mais exacerbada, mormente no atual viés de retorno à práticas liberais de mercado, batizado de neoliberalismo.

Enfim, segundo Dallari ${ }^{30}$, "o simples intervencionismo de Estado nada tem a ver com o socialismo, pois, consoante a observação irônica do próprio Lenin, se o monopólio do tabaco qualificasse o governo como socialista, Napoleão e Metternich deveriam ser considerados os precursores do socialismo".

28 La proprietà nell'esperienza giuridica contemporanea, p. 29.

29 Para o ultrapassamento da visão conservadora, ver Celso Antônio Bandeira de Mello, Eficácia das normas constitucionais sobre justiça social, e Eros Roberto Grau, Direito, conceitos e normas jurídicas, cit. e, também deste autor, A Ordem Econômica na Constituição de 1988 (Interpretação e Crítica).

30 Elementos de teoria geral do Estado, cit., p. 251. 


\section{O Princípio da Lucratividade}

\subsection{O conceito de economicidade}

Lucratividade traduz a idéia econômica de lucro, de obtenção de mais valia dentro de um sistema de produção capitalista, tal como acima referido, ou seja, da perseguição do incremento da mais valia, do lucro no sentido de ser tanto melhor quanto maior. Este é o sentido econômico de lucro capitalista.

O sentido jurídico do Princípio da Lucratividade, contudo, não deve seguir integralmente o senso econômico. Deve se revestir de conteúdo jurídico e ter por base o Estado Democrático de Direito insculpido no ordenamento jurídico e seguir o estado da cultura, que foi mencionado ao norte.

Um primeiro esboço para esta construção pode ser verificado em Francesco Galgano $^{31}$, ao traçar o sentido do conceito de economicidade, existente em normas do direito italiano, que obriga as empresas estatais a trabalhar "segundo critérios de economicidade" ${ }^{32}$. Para este autor, o conceito de economicidade, que ele analisou vinculado às empresas estatais, equivale à "auto-suficiência de gestão", que seria a obrigação que estas empresas teriam de "alimentar-se com suas próprias receitas e não efetuar gastos a fundo perdido da dotação patrimonial do ministério e dos aportes que este recebe do Estado". Obrar segundo critérios de economicidade, prossegue este autor, "significa, precisamente, respeitar o modo de produção capitalista: tender a remunerar os fatores produtivos utilizados significa, em particular, observar a 'lei' suprema da economia capitalista, a da reprodução do capital." ${ }^{33}$ A lógica da adoção deste critério, segundo Galgano, seria a de evitar que a empresa pública atuasse segundo critérios políticos, vindo a oferecer seus bens ou serviços de tal modo que pudesse remunerar os fatores de produção que lhe estivessem afetados.

Este conceito utilizado por Galgano para o critério de economicidade é apenas um primeiro esboço do que entendo deva ser entendido como Princípio da Lucratividade, porque ele se refere tão-somente a atuação de empresas estatais, e no sentido de evitar a manipulação de preços em detrimento do dinheiro público, decorrente do orçamento, que seria necessário para fazer frente aos déficits que ocorreriam na hipótese dessas empresas não laborarem sob a batuta dos saldos ativos de balanço. Como adiante será exposto, o que entendo por Princípio da Lucratividade é mais abrangente.

Outra construção existente sobre o conceito de economicidade é desenvolvida por Washington Peluso Albino de Souza ${ }^{34}$ que denomina "principio de economicidade", para quem este termo significa "uma linha de maior vantagem nas decisões da política econômica", cuja função é a de "ajustamento das medidas das medidas de política econômica aos princípios ideológicos adotados na Constituição". Pros-

31 Las Instituciones de la Economia Capitalista, p. 165-177.

32 Instituciones..., p. 168.

33 Instituciones..., p. 171.

34 Direito econômico, p. 28 e ss., especialmente a pág. 32. 
segue o grande autor mineiro: “assim, economicamente justo, segundo o princípio da economicidade introduzido neste contexto, é o que se põe em prática por medidas de política econômica, visando realizar o que sua soberania democrática tenha definido na Constituição, como fundamento dos princípios ideológicos que a inspiram".

Modesto Carvalhosa ${ }^{35}$ chama de economicidade a "técnica econômica aplicada no tratamento do fato ou do dado econômico, a qual se insere, por sua vez, na técnica legislativa, tendo como objetivo a realização do justo sócio-econômico."

Tanto Carvalhosa quanto Peluso visualizam o conceito de economicidade como o conteúdo da norma de direito econômico, sua implicações e repercussões vinculadas a medidas de política econômica. Veremos adiante que se trata de uma visão próxima daquilo que procurarei definir como conteúdo jurídico do Princípio da Lucratividade.

Também a Constituição de 1988, em seu artigo 70 , ao determinar competência ao Congresso Nacional para proceder à fiscalização contábil, financeira, orçamentária, operacional e patrimonial da União e das entidades da administração direta e indireta, inclui, ao lado da legalidade e da legitimidade, o critério de economicidade, entendido neste conceito o procedimento que visa alcançar as finalidades estabelecidas pela Administração Pública através do menor custo econômico possível. Este conceito também não se confunde com o que irei relatar, muito embora dele esteja próximo.

\subsection{Elementos para a compreensão do Princípio da Lucratividade}

Entendo que o Princípio da Lucratividade possui um conteúdo jurídico diverso do que foi referido para a economicidade. Há uma conjugação de princípios constitucionais que nos possibilitam descobri-lo no ordenamento jurídico.

Apenas para efeitos didáticos comecemos pelo art. 170 da Carta de 1988, onde se encontram agasalhados vários dos Princípios acima referidos como fundamentais para o desenvolvimento do Estado Liberal: Princípio do Direito de Propriedade, do qual decorre o da Propriedade Privada dos Bens de Produção, e o da Liberdade de Iniciativa, que encerra o Princípio da Liberdade de Contratar, permitindo o desenvolvimento de atividades econômicas por parte dos agentes privados, de conformidade com os meios que o ordenamento jurídico estabelecer, dentre vários outros. Estes Princípios decorrem do sistema capitalista e traduzem um regime econômico liberal de mercado, onde os agentes privados poderiam lutar para alcançar o lucro capitalista, no qual sua maior quantidade seria o melhor possível. Logo, estes Princípios, que decorrem da adoção de um sistema capitalista, permitem que se possa afirmar que o Princípio da Lucratividade possibilita aos agentes econômicos que ajam em busca do lucro no desenvolvimento de suas atividades. $\mathrm{E}$ toda e qualquer ação que venha a impedir esta busca pelo lucro será indevida e deverá ser objeto de

35 Direito econômico, cit., p. 318-9 
uma indenização. Por óbvio, não é toda e qualquer limitação ao lucro que gerará uma indenização, como adiante será melhor demonstrado. Questões de mercado e de gestão negocial podem levar os agentes econômicos a prejuízos, ou até mesmo à falência, sem que lhes caiba nenhum direito à indenizações.

Assim, o que se reafirma, é que um dos aspectos do Princípio da Lucratividade reconhece aos agentes econômicos o direito à busca pelo lucro, o que decorre do sistema capitalista adotado em nosso país, e referendado pelos Princípios Constitucionais acima mencionados.

Todavia - e já se começa a delinear um segundo aspecto do Princípio da Lucratividade - , estes Princípios liberais de mercado são mitigados por outros Princípios, que traduzem um regime Intervencionista, ou, por outras palavras, um Estado Social de Direito. Vários destes Princípios encontram-se também no art. 170 da Carta de 1988, dentre eles o da Função Social da Propriedade, da Defesa do Consumidor, da Defesa da Concorrência, da Defesa do Meio Ambiente e da Busca pelo Pleno Emprego. Tal conjugação de forças indica que os Princípios que estabelecem um regime econômico liberal não podem ser interpretados isoladamente. Daí porque a busca do lucro, em um regime econômico intervencionista como o brasileiro atual (a despeito das incontáveis reformas neoliberais implementadas na Carta de 1988) não pode permitir a busca desenfreada pelo lucro abusivo. E nem pode permitir que haja um impedimento à busca de uma certa lucratividade, neste aspecto traduzida como saldo ativo de balanço. As limitações encontram-se em vários dos aspectos acima mencionados, e que se traduzem em ações limitadoras do lucro liberal capitalista perfeitamente adequadas ao ordenamento jurídico brasileiro atual. Daí porque são perfeitamente legítimas as limitações ao lucro liberal-capitalista estabelecidas como proteção da concorrência, do consumidor, do meio ambiente efetuadas pelo ordenamento jurídico brasileiro.

A vedação ao lucro abusivo tem ainda um outro primado, que é o do Princípio da Dignidade da Pessoa Humana, fundamental e basilar para esta análise, uma vez que é a partir da existência da mais valia que o sistema capitalista se desenvolve. É medida profilática para o desenvolvimento da sociedade estabelecer restrições à extração da mais valia por parte dos detentores dos meios de produção a fim de que a pessoa humana não seja vilipendiada em seu bem mais precioso, que é sua dignidade. Logo, a prática de salários infames que gerem lucros fabulosos afronta a dignidade humana, e devem ser coibida. E este é o segundo aspecto gerado pela interseção deste conjunto de Princípios que geram o Princípio da Lucratividade. Outro exemplo que pode ser referido diz respeito à deliberada política econômica de recessão, geradora de desemprego. Neste aspecto estaremos falando da possibilidade de violação do Princípio da Lucratividade em razão da impossibilidade estabelecida pelo Estado (condutor da política econômica) de que os agentes privados obtenham uma margem mínima de lucro, onde sequer os saldos ativos de balanço conseguiriam ser alcançados e que o Princípio da Busca pelo Pleno Emprego, constante do art. 170, VIII, da Carta de 1988 seja alcançado.

Verifica-se, portanto, que o conteúdo jurídico do Princípio da Lucratividade não indica a busca desenfreada pelo lucro capitalista, mas a busca de um equilíbrio entre a impossibilidade de alcançar margens de lucro mínimas que permitam o desenvol- 
vimento dos negócios sociais, e a imoralidade da perseguição alucinada pela obtenção da maior quantidade de mais valia que for possível, ou seja, através da maior exploração do homem pelo homem, que implique em violação ao Princípio da Dignidade da Pessoa Humana. Enfim, o fundamento último da limitação ao exercício abusivo do direito de lucro é o Princípio da Dignidade da Pessoa Humana, que impõe a limitação à exploração da mais valia.

Será que o mercado é capaz de estabelecer esta limitação ao exercício abusivo do direito de lucrar? Por óbvio que não. O sistema econômico capitalista concorrencial produz distorções de mercado, que impedem seu livre exercício. Decorre daí que muitas atividades econômicas, em razão de seu exercício abusivo, acarretam o surgimento de práticas anticoncorrenciais de mercado, tal como ocorre com o surgimento de monopólios, oligopólios, monopsônios, cartéis, práticas de dumping etc. $\mathrm{O}$ direito da concorrência visa impedir este exercício abusivo de direito, que lesa a concorrência e, em última análise também o consumidor, acarretando o surgimento de lucros abusivos, que devem ser combatidos também em nome do Princípio da Dignidade da Pessoa Humana. Desta forma, a redução do lucro abusivo se caracteriza como um segundo aspecto do Princípio da Lucratividade.

Em resumo, pode-se dizer que o conteúdo jurídico do Princípio da Lucratividade se reveste de dois aspectos: o primeiro, que se traduz em um "direito" à busca de lucros; e o segundo, que do anterior é incindível, que se traduz no "dever" de não ter lucros abusivos, conforme estabelecem os citados Princípios Constitucionais constantes do art. 170, e regidos pelo Princípio da Dignidade da Pessoa Humana (art. $1^{\circ}$, III, CF/88) que dão suporte ao Princípio da Lucratividade.

Portanto, o conteúdo jurídico do Princípio da Lucratividade deve ser entendido como tendo várias funções, dentre elas a de "impedir" o exercício abusivo do direito de lucrar, bem como de "garantir" o direito à busca de um mínimo de lucro em face de ações omissivas ou comissivas do Estado que venham a impedir este exercício.

\subsection{Limitação de Lucros e Danos}

Observe-se que limitação do lucro não é dano, mas medida de ordem econômica adotada pelo Estado no interesse da manutenção do sistema capitalista, uma vez que os confrontos de classe existentes durante o Estado Liberal, se conduzidos a extremos, levariam à desagregação do regime capitalista. Logo, o Estado Intervencionista se impôs, visando a manutenção da sociedade de classes, envolta sob o véu do "bem comum", e servindo de anteparo para as reivindicações sociais. Consequientemente, esta limitação do lucro não é um dano, mas uma forma de política econômica.

Diversamente ocorre com o prejuizo econômico ocasionado pelo Estado, que não pode ser considerado como uma política econômica. Nenhum Estado pode, impunemente, levar os agentes econômicos à obtenção de prejuízos através de normas de direção. O Estado é co-partícipe na condução da política econômica adotada através de normas de direção, e o prejuízo ocasionado a um agente econômico, se tiver relação de causalidade com a política econômica de direção imple- 
mentada, deverá ser indenizado. E isto por ser um imperativo do sistema econômico adotado nos países que optaram por um modelo intervencionista de Estado, e não por um modelo tecnoburocrático (ou aparentemente socialista).

Deste modo, para a manutenção do sistema capitalista é imperativa a intervenção do Estado. Contudo, esta não pode ocorrer de tal forma que sufoque a sua própria razão de ser. O lucro deve ser mantido, mesmo que em reduzidos percentuais. A limitação do lucro é permitida como um imperativo da manutenção do sistema, a fim de que os economicamente hipossuficientes possam manter-se; afinal, a estrutura econômica do Estado Intervencionista, tal como era a do Estado Liberal, impõe a existência de classes. Conseqüentemente, importa na manutenção de todas elas para que este Estado como tal se mantenha.

Ressalte-se que nem todo prejuízo econômico pode ser considerado como um dano. Pode ocorrer, como, por exemplo, nos empreendimentos de vulto em fase de implantação, que seja previsto um prejuizo operacional nos primeiros exercícios, a fim de que a atividade possa tornar-se lucrativa com o correr do tempo.

Ademais, é importante determinar contabilmente o que deve ser entendido como verdadeiro prejuízo econômico. Se este deve ser apurado segundo critérios anuais, ou mensais; se com base em balanços levantados para esta verificação ou no balanço efetuado segundo as regras contábeis usuais etc. Tal determinação deverá ser efetuada pelo ordenamento jurídico positivo de cada país, obedecendo a critérios peculiares a cada qual.

Logo, é imprescindível fazer provada relação de causalidade entre a norma de direção invocada como causadora de prejuízo econômico e a materialidade deste.

Se, em uma hipótese absurda, o Estado determinasse que em certa região só se plantasse morangos, sendo esta área inservível para o plantio desta fruta, o Estado seria responsável pelos maus resultados produzidos. $O$ fato de este hipotético agricultor ter obtido prejuízo com o plantio de morangos, tal como imposto pelo Estado, faz com que este se vincule ao resultado, sendo diretamente responsável por ele. Obviamente este é um esquema teórico, pois na realidade muitas outras variantes irão influir no resultado superavitário ou deficitário do empreendimento. Todavia, se apurado que o resultado foi deficitário e que o Estado foi o responsável por parcela deste déficit em razão de sua política econômica de direção, um ressarcimento amplo se impõe, proporcional à parcela a que deu causa.

Os Tribunais brasileiros não estão desatentos para o problema, muito embora muitas vezes questões de ordem processual impeçam o verdadeiro deslinde da questão. Um exemplo é a ementa do Agravo de Instrumento 52.907-DF, publicado no DJU (4 fev. 1988, p. 1238), julgado pela Terceira Turma do Tribunal Federal de Recursos, que assim tratou da questão:

“Liminar objetivando reajustamento de preços acima das tabelas oficiais. Indeferimento pelo juiz.

Não se pode negar à Comissão Interministerial de Preços (CIP) o poder de estabelecer a política de preços e baixar tabelas. Ainda que se entenda não ser possível impor à iniciativa privada a venda de produtos abaixo do preço de produção, a verificação desta última questão, por dependente de prova que não deve ser excluída do contraditório, escapa ao exame sumaríssimo 
da liminar 'inaudita altera parte'.

Questões complexas e difíceis não devem ser examinadas na fase inicial da ação.

Agravo de instrumento a que se nega provimento."

Esta decisão, a despeito de colocar a descoberto o problema, não lhe dá solução, preferindo deixá-lo de lado por questões de ordem processual. Ademais, não enfoca a questão da responsabilização, mas a do desfazimento da norma de tabelamento.

Um caso exemplar pode ser encontrado no Supremo Tribunal Federal quando analisou o pedido de companhias de aviação brasileiras que tiveram suas tarifas aéreas "congeladas" pelo Governo Federal sob a égide do Plano Cruzado, em 1986. O acórdão, que teve como relator o Ministro Octávio Gallotti foi assim ementado:

“Prejuízo julgado comprovado pelas instâncias ordinárias e decorrente de atos omissivos e comissivos do Poder concedente, causadores da ruptura do equilíbrio financeiro da concessão, não abstratamente atribuível a política econômica, normativamente editada para toda a população ("Plano Cruzado").

Recurso extraordinário de que, em conseqüência, não se conhece, ..."36

No voto, o Ministro Gallotti asseverou, verbis:

“Desrespeitado este princípio por ato comissivo ou omissivo do Poder Concedente, impõe-se a recomposição da equação financeira, tendo em vista não só a imperiosa necessidade de que os servidores (sic) públicos tenham continuidade, mas também em razão do princípio jurídico que preconiza que todo aquele que, por ação ou omissão, causar prejuízo a outrem, fica obrigado a reparar o dano (Código Civil, art. 159)."

Este mesmo tipo de raciocínio é seguido pelos demais Tribunais. Ver, por todos, alguns julgados do Tribunal Regional Federal da $1^{\mathrm{a}}$ Região:

Juíza Eliana Calmon:

“Contrato de Concessão de serviço público firmado entre a União e as empresas de transporte aéreo, que não se identifica como mera permissionária, conforme avença firmada entre as partes. (...) Tarifas aéreas fixadas pela União, via DAC, com defasagem do preço de custo e sofrendo, ainda os efeitos da inflação. Prejuízo suportado pelas empresas e que autorizam indenização pela União causadora do desequilíbrio (precedentes jurisprudenciais). ${ }^{37}$. 
"Demonstrada a quebra do equilíbrio econômico-financeiro do contrato de concessão de transporte aéreo, por força de congelamento imposto à concessionária em decorrência de planos econômicos governamentais, impõe-se à concedente o dever de indenizar os prejuízos comprovados em perícia regularmente processada, uma vez que violou direito da outra parte contratante, assegurada em cláusula expressa da respectiva avença." ${ }^{38}$.

Verifica-se que a jurisprudência mencionada deu extrema relevância ao fato de que a relação entre as partes era de concessão de serviços públicos, contudo, entendo que esta situação teria de receber o mesmo desfecho indenizatório mesmo que não houvesse relação contratual entre as partes envolvidas, simplesmente em decorrência da violação do Princípio da Lucratividade por uma norma de direção.

Outro caso do Supremo Tribunal Federal extremamente interessante e que merece destaque para melhor explicitar este Princípio é a decisão relatada pelo Ministro Orosimbo Nonato, RE 18.331, na qual se pronunciou alertando que " $o$ poder de taxar não pode chegar à desmedida do poder de destruir, substituído o conhecido axioma de Marshall de que 'the power to tax is the power to keep alive'. Cita ainda o juiz erudita conferência do prof. Bilac Pinto, tirada a lume na Rev. Forense vol. 82, p. 547, que vale por eloqüente preconício da doutrina elaborada na Corte Suprema dos Estados Unidos, de que o poder de taxar 'só pode ser exercido dentro dos limites que o tornem compativel com a liberdade de trabalho, comércio e da indústria e com o direito de propriedade'. É um poder, em suma, cujo exercício não pode ir até o abuso, o excesso, o desvio, sendo aplicável, ainda aqui, a doutrina fecunda do 'detournemente de pouvoir'. Não há que estranhar a invocação dessa doutrina ao propósito da inconstitucionalidade, quando a Justiça argentina já proclamou que 'la inconpatibilidad puede ser con la letra de la Constitución, o solamente com su espírito, es decidir, com su verdadero significado quando la letra es obscura o da lugar a diversas interpretaciones'." ${ }^{39}$

Engana-se, contudo, quem entende que tal belíssimo acórdão concedeu ganho de causa ao contribuinte. Muito pelo contrário. No caso em apreço, o Município de Santos havia majorado o valor do imposto de licença sobre cabines de banho para o exercício de $1949 \mathrm{em} 1.044,00 \%$. O contribuinte entendeu que tal majoração estava desproporcional à sua capacidade econômica. A decisão de 1 a. instância foi favorável ao contribuinte, mas o Tribunal de Justiça do Estado de São Paulo reformou a sentença. O Ministro Orosimbo Nonato, após o magnífico pronunciamento acima transcrito, decidiu que no caso concreto não havia sido a majoração do imposto que lhe causava dano à capacidade contributiva, uma vez que "o que mais onera sua situação é o pagamento do aluguel do prédio, devido, em 1948, à razão de oitenta

39 www.stf.gov.br, acórdão na íntegra. Pequeno excerto deste acórdão foi mencionado por Gilmar Ferreira Mendes, em A Proporcionalidade..., pág. 475. 
e dois mil cruzeiros para cento e cinquienta mil cruzeiros em 1949, exercício a que se refere o lançamento cobrado (...) É evidente que o fisco nada tem a ver com os contratos onerosos dos contribuintes. Se o imposto que cobra é legal e devido, e não se mostra, só por si, exorbitante ou extorsivo, não há que ser acoimado de inconstitucionalidade (...) Manifesto é, pois, que a contribuição devida ao fisco não se mostra onerosa ou absorvente de seus lucros. Absorvente e onerosa é a orientação adotada de exploração de seus negócios, capaz de consumir a quase totalidade de seus lucros. E só por isso não fica inibido o fisco de arrecadar a seus tributos, legitimamente lançados."

Tal acórdão demonstra, à saciedade, que não se pode dizer que toda e qualquer limitação à obtenção de lucros, inclusive a implementada através de normas fiscais, seja uma violação do Princípio da Lucratividade. Condução ruinosa dos negócios privados também pode levar ao prejuízo, sem que possa alegar a infringência ao Princípio da Lucratividade. O direito à busca de lucro foi assegurada, e a eventual limitação ao lucro abusivo imagina também poderia vir a ser invocada. A não ocorrência de lucro, no caso em apreço relatado pelo Ministro Orosimbo Nonato, foi devida pela má gestão dos negócios, segundo consta do acórdão, não sendo pertinente se referir ao Princípio da Lucratividade em prol do agente econômico.

\section{Conclusões:}

O Princípio da Lucratividade decorre do sistema capitalista, no qual convivem os regimes econômicos liberal e intervencionista, que se traduzem em expressões estabelecidas pelo próprio desenvolvimento econômico da sociedade, e traduzidas em diversos Princípios Constitucionais, vários dos quais constantes do art. $170 \mathrm{da}$ Carta de 1988, sendo seu Princípio fundamental o da Dignidade da Pessoa Humana, inserto no art. $1^{\circ}$, III, da carta de 1988.

O conteúdo jurídico do Princípio da Lucratividade se traduz em dois distintos aspectos: o primeiro, que reconhece aos agentes econômicos o direito pela busca de lucro liberal capitalista; e o segundo, que daquele é indissociável, que obriga a limitação daquele lucro, por infringir o Princípio da Dignidade da Pessoa Humana e, com isso, dar ensejo à manutenção do próprio sistema capitalista.

\section{Bibliografia Utilizada:}

ALVES, Alaôr Caffé. Estado e ideologia; aparência e realidade. São Paulo, Brasiliense, 1987.

ATHAYDE, Augusto de. Estudos de direito econômico e de direito bancário. Rio de Janeiro, Ed. Liber Juris, 1983.

Bandeira de Mello, Celso Antônio, Eficácia das normas constitucionais sobre justiça social. RDP, São Paulo, Revista dos Tribunais, 57/58:233-56, jan./jun. 1981.

BEARD, Charles. Una interpretación econômica de la Constitución de los Estados Unidos. Buenos Aires, Ed. Arayú, s.d. 
BONAVIDES, Paulo. Do Estado Liberal ao Estado Social. 4. ed. Rio de Janeiro, Forense, 1980.

Curso de Direito Constitucional. SP, Malheiros, $5^{\text {a }}$ ed., 1994.

CARVALHOSA, Modesto. Direito econômico. São Paulo, Revista dos Tribunais, 1973.

COMPARATO, Fábio Konder. Educação, Estado e Poder. SP, Brasiliense, 1987. . Ensaios e pareceres de direito empresarial. COMPARATO, Fábio Konder. Rio de Janeiro, Forense, 1978.

CORREAS, Óscar. Sociología del Derecho y Crítica Jurídica. México, Ed. Fontamara, 1998.

DALLARI, Dalmo. Elementos de teoria geral do Estado. 12. ed. São Paulo, Saraiva, 1986.

FRADERA, Véra Jacob de A Integração Européia e o Mercosul: Confronto Atual, Direito da Concorrência e Integração em Perspectiva Comparatista. Rev. de Direito do Consumidor, vol. 31, ano 99, págs. 86-95.

GALGANO, Francesco. História del derecho mercantil. Trad. Joaquim Bisbal. Barcelona, Ed. Lara, 1980.

Las Instituciones de la Economia Capitalista. Bologna, Zanichelli, 1977.

GIANNINI, Massimo Severo. Diritto pubblico dell'economia, Bologna, Il Mulino, 1977.

GOZZI, Gustavo. Verbete Práxis, elaborado por, pág. 987. In: Bobbio, Norberto et alii. Dicionário de Política. Brasília, Ed. UnB, 1992, vol. 02.

GRAU, Eros Roberto. O Direito Posto e o Direito Pressuposto. SP, Malheiros, 1996. Direito, conceitos e normas jurídicas. São Paulo, Revista dos Tribunais, 1988.

A Ordem Econômica na Constituição de 1988 (Interpretação e Crítica). SP, Malheiros, 3a. ed., 1997.

LASSALE, Ferdinand, Que é uma Constituição? Rio de Janeiro, Ed. H. Laemmert, 1969.

MARX, Karl. O Capital, vol. I. Trad. Régis Barbosa e Flávio Kothe. 2. ed. São Paulo, Nova Cultural, 1985.

MENDES, Gilmar Ferreira. A Proporcionalidade na Jurisprudência do Supremo Tribunal Federal, Repertório IOB de Jurisprudência, ementa ${ }^{\circ} 1-8175,1^{a}$ quinzena de dezembro de $1994, \mathrm{n}^{\circ} 23 / 94$, página 475 e ss.

MOREIRA, Vital. A ordem jurídica do capitalismo. Coimbra, Ed. Centelha, 1973.

MÜLlER, Friedrich. Quem é o Povo? A Questão Fundamental da Democracia. SP, Max Limonad, 1998.

NUSDEO, Fábio. Da política econômica ao direito econômico. Tese de Livre-docência em Direito Econômico apresentada à Faculdade de Direito da Universidade de São Paulo, 1977.

SCAFF, Fernando Facury. Responsabilidade Civil do Estado Intervencionista. $2^{\mathrm{a}} \mathrm{ed}$. RJ, Renovar, 2001.

Processo Tributário e Estado Democrático de Direito. In: MARTINS, Ives Gandra da Silva (Coord.). Processo administrativo tributário. São Paulo: Ed. Revista dos Tribunais: Centro de Extensão Universitária p. 511-527. 
SICHES, Luis Recaséns. Introduccion al estudio del Derecho, $12^{\mathrm{a}}$ ed. México, Ed. Porrúa, 1997.

SILVA, José Afonso da. Aplicabilidade das normas constitucionais. 2. ed. São Paulo, Revista dos Tribunais, 1982.

SOUZA, Washington Albino Peluso . Direito Econômico. São Paulo, Saraiva, 1980.

VIDIGAL, Geraldo de Camargo. Teoria geral do direito econômico. São Paulo, Revista dos Tribunais, 1977.

VITTA, Anna de. La proprietà nell'esperienza giuridica contemporanea. Milano, Giuffrè, 1969. 